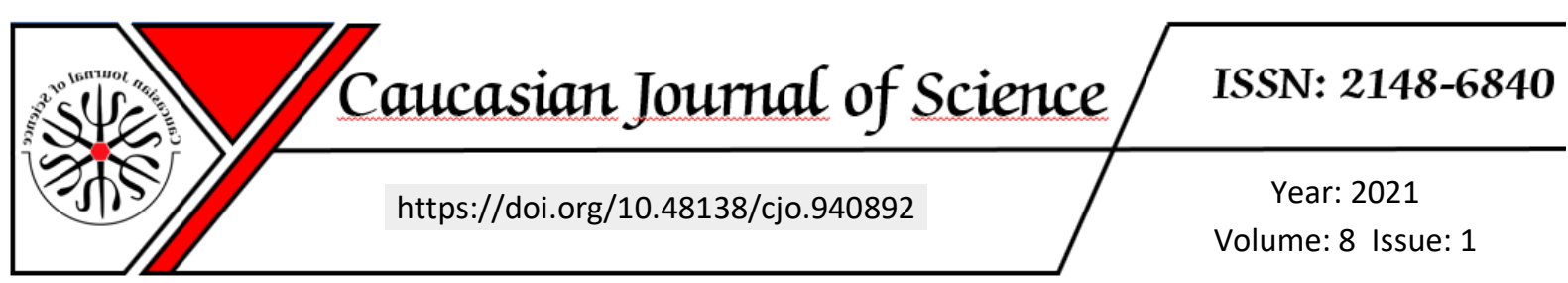

\title{
Yüksek Riskli Gebeliklerde Depresyon ve Anksiyete Düzeylerinin Sıklığının Değerlendirilmesi
}

\author{
Özlem KARABULUTLU ${ }^{1}$, Canan YAVUZ ${ }^{2}$
}

Makalenin Alanı: Sağlık

\section{Makale Bilgileri Öz}

Geliş Tarihi

22.05.2021

Kabul Tarihi

16.06.2021

Anahtar Kelimeler
Gebe
Riskli gebe
Depresyon
Anksiyete
Ebelik/hemşirelik
bakımı

Yüksek riskli gebelik; anne, fetüs ya da yenidoğanın hayatını ve sağlık durumunu tehlikeye sokan, morbidite ve mortalite risklerini arttıran, fizyolojik, ekonomik ve psikososyal durumlardır. Yüksek riskli gebeliklerde anne veya fetüse ait sorunların olması nedeniyle yaşanan stres, travma, endişe normal gebeliklere kıyasla daha fazla orandadır ve uzun vadeli bir psikolojik stres oluşumuna katkıda bulunurlar. Bu nedenle, bu araştırma yüksek riskli gebeler ile normal gebeliği olan bireylerin depresyon ve anksiyete düzeylerini bunların birbirleriyle olan ilişkilerinin incelenmesi ve yüksek riskli gebelik durumunda, ebelik/hemşirelik bakım kalitesini arttıracak öneriler sunmak amacıyla planlanmıştır. Nisan-Ekim 2016 tarihleri arasında Kars Harakani Devlet Hastanesi Kadın Hastalıkları ve Doğum Poliklinikleri'nde gerçekleştirilen bu tanımlayıcı araştırmanın örneklemini yüksek riskli gebe grubuna 95 ve kontrol grubuna 95 gebe olmak üzere 190 gebe dahil edilmiştir. Araştırmanın verileri amacına uygun hazırlanmış sosyodemografik bilgi formu ve Beck Depresyon Ölçeği (BDÖ) ve Beck Anksiyete Ölçeği (BAÖ) kullanılarak toplandı. Verilerin analizinde tanımlayıcı istatistikler (frekans, yüzde, ortalama, standart sapma), ki kare testi, t testi, Mann Whitney U testi ve basit doğrusal regresyon testi kullanıldı. Sonuçlar \%95 güven aralığında değerlendirildi. Bu araştırmada yüksek riskli gebelerin \%28,4'ünde depresyon, $\% 32,6$ 'sında orta ve şiddetli düzeyde anksiyete tespit edildi. Yüksek riskli gebelerde depresyon ve anksiyete görülme oranı, normal gebelerle benzer bulundu $(p>0,05)$. Yüksek riskli gebelerde gebelik öncesi psikiyatrik tedavi alanların depresyon ortalamalarının yüksek olduğu belirlendi $(p<0,05)$. Depresyon belirtilerinin gözlendiği gebelerin anksiyete ortalamalarının da yüksek olduğu belirlendi $(p<0,05)$. Bu araştırmada yüksek riskli gebeler diğer gebelere benzer oranda anksiyete ve depresyon yaşamakta ve gebeliğin yüksek riskli olması bu oranları etkilememektedir. Araştırmaya göre yüksek riskli gebelerin yaşadığı gebelik öncesi veya gebelik sırasında oluşan risk faktörlerinin anksiyete ve depresyon oluşmasında etkili olmadığı söylenebilir. Bu sonuçlara dayanarak yüksek riskli gebelerde anksiyete ve depresyon düzeylerinin düzenli aralıklarla değerlendirilmesi, görev alan tüm ebe/hemşirelerin bakım ve danışmanlık uygulamalarının yeri ve önemi kanıta dayalı olarak yeniden sorgulanmalıdır.

\begin{tabular}{ll}
\hline Article Info & Abstract \\
\hline Received & High-risk pregnancy; These are the physiological, economic and psychosocial conditions \\
that endanger the life and health of the mother, fetus or newborn and increase the
\end{tabular}

\footnotetext{
${ }^{1}$ Kafkas University Faculty of Health Sciences Department of Midwifery-Kars; e-mail: okarabulutlu@gmail.com; ORCID: 0000-0001-5307-5186 (Sorumlu Yazar)

${ }^{2}$ Midwife Çerkezköy İstasyon Family Health Center-Tekirdağ; e-mail: cnn_ywz@hotmail.com; ORCID: 0000-0003-4661-2929
} 


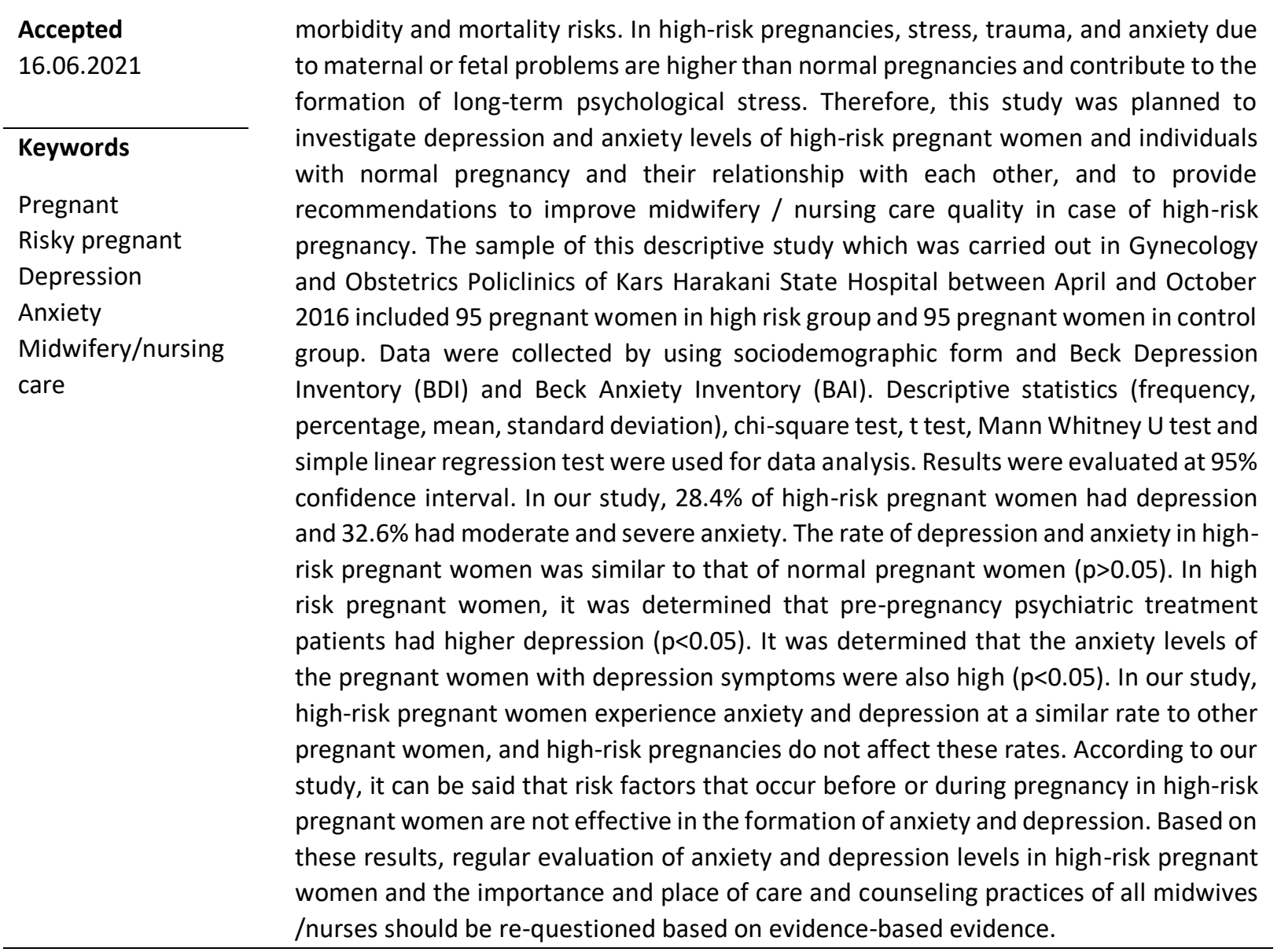

\section{GiRiş}

Gebelik ve perinatal dönem, bir kadının yaşamında fertilizasyonla başlayan ve hem kadının vücudunu hem de diğer kısımlarını ilgilendiren birçok değişikliğe neden olan ve bu anlamda hem fiziksel hem psikolojik hem de sosyal adaptasyonu gerektiren stres yaşanmasına neden olabilecek özel olaylardır (Satyapriya et al., 2013; Koss et al., 2016). Yüksek riskli gebelik; anne, fetüs ya da yenidoğanın hayatını ve sağlık durumunu tehlikeye sokan, morbidite ve mortalite risklerini arttıran, fizyolojik, ekonomik ve psikososyal durumlardır (Özkan ve ark., 2004). Yüksek riskli gebelikler, kadının gebelik öncesine ait bir sağlık sorunundan (kalp hastalığı, diyabet, hipertansiyon gibi) kaynaklı gelişebildiği gibi, gebelik sürecinde (preeklampsi, eklampsi, kanama gibi) de ortaya çıkabilmektedir. Yüksek riskli gebeliklerde anne veya fetüse ait sorunların olması nedeniyle yaşanan stres, travma, endişe normal gebeliklere kıyasla daha fazla orandadır (Shin and Kim, 2011) ve uzun vadeli bir psikolojik stres oluşumuna katkıda bulunurlar (Kossakowska, 2016). Yüksek riskli gebeliklerde stresörlerin farkında olunup, uygun danışmanlık ve stresle baş etme yöntemleri kullanılması ile anne, fetüs veya bebeğin sağlık durumunun daha iyi olması sağlanabilir (Ölçer ve Oskay, 2015). Gebe 
kadınlar, genetik faktörlere, kişilik özelliklerine, geçmiş tecrübelere, aile ve sosyal çevre desteğine göre yüksek riskli gebeliğe farklı tepkiler verebilmektedir (Satyapriya et al., 2013; Ölçer ve Oskay, 2015; Serçekuş ve Okumuş, 2004). Uyum sağlamaya çalıştığı bu dönem kendisini hem kadın hem de anne olarak yetersiz ve başarısız hissetmesine, düşük benlik algısına ve de annelik becerisine güvenmemesine sebep olabilir (Ölçer ve Oskay, 2015). Duygularını da öfke, kaygı, korku, saldırganlık, çaresizlik, içe dönüklük gibi benzeri davranışlarla sergileyebilir (Ölçer ve Oskay, 2015). Bu belirtilerin yoğun olması, kadının çocuğun doğumuna eşlik eden biyolojik, psikolojik ve sosyal değişiklikleri düzenleme yetisini, prenatal bakım almayı ve obstetrik süreci olumsuz etkileyebilir. Bu belirtilerin doğum öncesi dönemde uygun şekilde ele alınmayıp, doğum sonrası dönemde de sürmesi, anne-bebek ilişkisini ve bu yolla da bebeğin bilişsel-davranışsal gelişimi üzerinde olumsuz etkilere sebep olabilmektedir (Özkan et al., 2004; Gümüşdağ ve ark., 2014; Dugalic, 2013). Bu sonuçlar antenatal dönemde psikiyatrik bozukluğun erken dönemde tanı ve tedavisinin önemli olduğunu gösterir (Özkan et al., 2004). Anksiyete ve depresyon, gebeliğin sağlıklı ilerlemesini etkileyebilecek stres yüklü durumlara karşı iki genel yanıttır (Satyapriya et al., 2013). Gebenin anksiyete düzeyinin artması depresif semptomları arttırarak depresyona neden olabileceği gibi depresyon düzeyindeki artma anksiyeteyi arttırabilmektedir (Şahin ve Kılıçarslan, 2010). Farklı toplumlarda gebelik sürecinde depresyon ve anksiyete görülme sıklığını araştıran çalışmalarda depresyon ve depresif belirtilerin görülme sıklığı Macaristan'da \%17,9 anksiyete görülme sıklığı 14.6, Finlandiya'da depresyon \%30 anksiyete \%16, Sırbistan'da depresyon görülme sıklığı \%21,7 olarak bulunmuştur. Türkiye'de Beck Depresyon Ölçeği'ne göre yapılan çalışmalar da gebelik sürecinde depresyon ve depresif belirti görülme sıklığını; Erdem ve arkadaşları (2010) \%31, Karaçam ve Ançel (2009) \%27,9 olarak bulmuşlardır (Erdem ve ark., 2010; Karaçam ve Ançel, 2009). Tunç ve arkadaşları (2012) gebelerin \%32'sinin anksiyete, \%47'sinin depresyon yaşadığını bulmuşlardır (Tunç ve ark., 2012). Riskli gebeliğe sahip olgularda anksiyete ve depresyon ortalamaları, gebeliğinde risk faktörü saptanmayan olgulara göre yüksek bulunmuştur (Pişirgen, 2011). Ayrıca Paşalak (2016) çalışmasında yüksek riskli gebelerin gebeliğe uyum sağlamada sorun yaşadıklarını saptamıştır (Paşalak, 2016).

Gebelik dönemindeki fizyolojik tepkiler kadar olumsuz psiko-sosyal tepkilerin de tanınarak önlenmesi, anne-bebek sağlığı üzerinde olumsuz etkilerinin azaltılarak ve koruyucu ruh sağlığı hizmetlerinin geliştirilebilmesi yönüyle önemlidir (Marakoğlu ve Şahsıvar, 2008). Bütüncül bir yaklaşım açısından gebelik izlemlerinde tıbbi değerlendirme yapılırken, fiziksel 
değerlendirme ile birlikte psiko-sosyal değerlendirme yapılması ve risk etmenlerinin de değerlendirilmesi önemli olup normal, az riskli, riskli ve yüksek riskli olan gebeler ruhsal yönden bilgilendirilmelidir. Ebe ve hemşireler doğum öncesi bakım hizmeti sürecinde, risklerle ilgili bilgileri değerlendirerek, tanımlayıp, uygun girişimleri planlayabilmelidir (Taşkın, 2016). Gebeliğin anne ve fetüs sağlığını etkileyen depresyon semptomlarına neden olabileceği ve yüksek riskli gebelikleri olan kadınların bu değişikliklere karşı daha savunmasız olduğunu gösteren bilimsel kanıtlar göz önüne alındığında, burada bildirilen çalışma ebelerin ve hemşirelerin; yüksek riskli gebelik durumunda, anne adaylarını ve yaşayabileceği sorunları erken tanımlanmasını, gerekli destek ve bakımın zamanında yapılmasını sağlayarak ebelik/hemşirelik bakım kalitesini arttıracaktır.

$\mathrm{Bu}$ araştırmada, yüksek riskli gebeler ile normal gebeliği olan bireylerin sosyodemografik özellikleri, depresyon ve anksiyete düzeyleri ve bunların birbirleriyle olan ilişkilerinin araştırılması amaçlanmıştır.

\section{MATERYAL VE METOT}

\subsection{Araştırmanın Tipi}

Tanımlayıcı tipteki bu araştırma, Kars Harakani Devlet Hastanesi Kadın Hastalıkları ve Doğum Poliklinikleri'ne doğum öncesi bakım hizmeti almak için gelen gebeler ile 15 Nisan-15 Ekim 2016 tarihleri arasında gerçekleştirilmiştir

\subsection{Araştırmanın Evreni ve Örneklemi}

Araştırmanın evrenini, Kars Harakani Devlet Hastanesi Kadın Doğum Polikliniklerine başvuran gebeler oluşturmuştur. Hastane kayıtlarına göre 2015 yılında, Harakani Devlet Hastanesi Kadın Doğum Polikliniğine başvuran yüksek riskli gebe sayısı 338'dir. Araştırmanın yüksek riskli gebe grubunu polikliniğe başvuran, araştırmaya katılmayı kabul eden ve yüksek riskli gebelik tanısı alan 95 gebe, sağlıklı gebe grubunu ise yüksek riskli gebelik tanısı olmayan 95 gebe oluşturmuştur. Gebeler araştırmacının veri toplama tarihlerinde polikliniğe başvuran gebeler arasından gelişigüzel yöntem ile seçilmiştir.

Gebelik izlemi sırasında saptanan yüksek risk faktörleri olarak alınan durumlar; hipertansif hastalıklar, şiddetli hiperemezis gravidarum, kilo alımında problemler, intrauterin gelişme geriliği (IUGG), polihidramnios veya oligohidramnios, prezentasyon anomalileri, diabetes mellitus, preterm veya postterm eylem, çoğul gebelik, akut cerrahi problemler, Rh izoimmünizasyonu, antenatal kanama olarak belirlenmiştir. 


\subsection{Veri Toplama Araçları}

Veri toplama araçları olarak anket formu, depresif belirtileri araştırmak için Beck Depresyon Ölçeği (BDÖ) ve anksiyete belirtilerini araştırmak için de Beck Anksiyete Ölçeği (BAÖ) kullanılmıştır.

Anket formunda gebelerin yaşları, eğitim düzeyleri, çalışma durumları, eşlerinin eğitim düzeyleri ve çalışma durumları, önceki gebelikleri ve doğum öyküleri, gebelik izlemi sırasında saptanan risk faktörleri, bu risk başlamadan önce önemli bir stres, psikiyatrik hastalık ve tedavi öyküsü, bebeğin istenme durumu gibi sorular yer almaktadır. Toplamda 24 sorudan oluşmaktadır.

Beck Depresyon Ölçeği (BDÖ), ilk kez 1961'de Aeoron T. Beck tarafından geliştirilmiş olup 1971'de tekrar gözden geçirilmiştir. 1988'de Hisli tarafından Türkçe'ye çevrilmiş, geçerliği yapılmış ve 1989 'da geçerlilik güvenilirliği gösterilmiştir. BDÖ, 21 maddelik bir kendi kendini değerlendirme ölçeği olup, depresif semptomları ve karakteristik yaklaşımları ölçmektedir. Dörtlü Likert tipi ölçüm sağlamaktadır. Hastalar ölçeğin üzerine işaretleyerek yanıt verirler. Her madde 0-3 arasında giderek artan puanlar alır ve bunların toplanması ile toplam puan elde edilir. Toplam puan 0-63 arasında değişir. Ölçeğin Türkçe için geçerlik ve güvenilirlik makalesinde kesme puanının 17 olarak kabul edildiği belirtilmiştir (Hisli, 1988; Hisli, 1989).

Beck Anksiyete Ölçeği (BAÖ), 1988'de Aeron T.Beck tarafından geliştirilmiş olup 21 maddelik bir kendi kendini değerlendirme ölçeğidir. Türkçe'ye Ulusoy ve arkadaşları tarafından 1998'de çevrilmiştir. BAE'deki maddelerde anksiyetenin subjektif, somatik ve panikle ilgili belirtileri tarif edilmektedir. Her madde 0'dan 3'e kadar puanlanan 4 seçenek içermektedir. 21 maddenin toplamında da 0-63 puan elde edilir ve toplam skorun artması anksiyete semptomlarının da arttığını gösterir (Ulusoy ve ark., 1998).

\subsection{Veri Toplama Yöntemi}

Veriler, araştırmacı tarafından katılımcılara araştırmanın amacı açıklanıp bilgi verilerek sözel onamları alındıktan sonra veri toplama araçları verilerek veri toplama formlarını doldurması ile yüz yüze görüşme tekniği kullanılarak 20 dakikada toplanmıştır.

\subsection{Araştırmanın Etik ilkeleri}

Araştırmanın uygulanabilmesi ve verilerin toplanabilmesi için Kafkas Üniversitesi Tıp Fakültesi Etik Kurulu'ndan 30/03/2016 tarih ve 04 numaralı oturumda etik kurul onayı alınmıştır. Araştırmanın Kars Harakani Devlet Hastanesi Kadın Doğum Poliklinikleri'nde yapılabilmesi için Kars Kamu Hastaneler Birliği Genel Sekreterliği'nden 14/04/2016 tarihinde 
yazılı izin alınmıştır. Ayrıca bu çalışmada kullanılacak olan ölçekler için de elektronik posta yoluyla onay alınmıştır. Araştırmaya dâhil edilen gebeler araştırma ile ilgili bilgilendirilmiş, bireysel bilgilerinin korunacağı ve istedikleri zaman araştırmadan çekilebilecekleri sözel belirtilerek gönüllü olanlar araştırmaya dahil edilmiştir. Böylece 'Gizlilik ve Gizliliğin Korunması', 'Aydınlatılmış Onam' ve 'Özerkliğe Saygı' ilkelerini içeren etik ilkeler yerine getirilmiştir.

\subsection{Araştırmanın Sınırlılıkları}

Araştırmada kullanılan veriler sadece araştırmaya katılan gebeleri temsil etmektedir. Bu nedenle, araştırma sadece bir hastanede yapılmış olmasından dolayı yalnızca o gruba genellenebilir.

\section{7. İstatistiksel Analiz}

Araştırmada elde edilen verilerin analizinde, SPSS 20.0 programı kullanılmıştır. Verilerin ilk olarak tanımlayıcı istatistikleri (frekans, yüzde, ortalama, standart sapma) hesaplanmış, ardından kategorik değişkenler arasındaki ilişkiler için ki-kare testi kullanılmıştır. Verilerin normal dağılıma uygunluğu test için Kolmogorov-Smirnov Testi'nden faydalanılarak normal dağılım gösteren sürekli değişkenleri analizde İndependent Sample t testi, normal dağılım göstermeyen sürekli değişkenleri analizde Mann Whitney $U$ testi kullanılmıştır. Sonuçlar \%95 güven aralığında, anlamlılık p<0,05 düzeyinde olarak kabul edilmiştir.

\section{BULGULAR}

Araştırmada yaş gruplarına bakıldığında; yüksek riskli gebelik tanısı olan olguların \%48,4'ünün 25-34 yaş aralığında, \%31,6'sının ilkokul mezunu, \%80'inin çalışmadığı ve \%20'sinin eşiyle akraba olduğu belirlenmiştir. Yüksek riskli gebelerin \%30,5'inin eşinin ilkokul mezunu ve \%88,4'ünün eşinin çalıştığı belirlenmiştir. Yüksek riskli gebelerin \%47,4'ünün gelirlerinin giderinden az, \%35,8'inin köyde yaşadığı, \%51,6'sının eşi ve çocuğu ile yaşadığı belirlenmiştir (Tablo 1). 
Tablo 1. Yüksek riskli gebelik tanısı alan ve almayan gebelerin demografik özelliklere göre dağılımı $(n=190)$

\begin{tabular}{|c|c|c|c|c|c|c|}
\hline \multicolumn{2}{|c|}{ Demografik Özellikler } & \multicolumn{2}{|c|}{ Yüksek Riskli Gebe } & \multicolumn{2}{|c|}{ Sağlıklı Gebe } & \multirow{2}{*}{\begin{tabular}{|c}
$\begin{array}{c}\text { Test anlamlılık } \\
\text { değeri } \\
\mathbf{p}\end{array}$ \\
\end{tabular}} \\
\hline & & $n$ & $\%$ & $n$ & $\%$ & \\
\hline \multirow[t]{4}{*}{ Yaş } & 18 ve altı & 8 & 8.4 & 7 & 7.4 & \multirow[t]{4}{*}{0.987} \\
\hline & $19-24$ & 30 & 31.6 & 31 & 32.6 & \\
\hline & $25-34$ & 46 & 48.4 & 45 & 47.4 & \\
\hline & 35 ve üzeri & 11 & 11.6 & 12 & 12.6 & \\
\hline \multirow[t]{5}{*}{ Eğitim düzeyi } & $\begin{array}{l}\text { Okuryazar değil/ } \\
\text { okuryazar }\end{array}$ & 10 & 10.5 & 13 & 13.7 & \multirow[t]{5}{*}{0.044} \\
\hline & ilkokul & 30 & 31.6 & 19 & 20.0 & \\
\hline & Ortaokul & 25 & 26.3 & 42 & 44.2 & \\
\hline & Lise & 10 & 10.5 & 10 & 10.5 & \\
\hline & Üniversite & 20 & 21.1 & 11 & 11.6 & \\
\hline \multirow[t]{2}{*}{ Çalışma durumu } & Çalışmayan & 76 & 80.0 & 81 & 85.3 & \multirow[t]{2}{*}{0.444} \\
\hline & Çalışan & 19 & 20.0 & 14 & 14.7 & \\
\hline \multirow[t]{4}{*}{ Meslek } & Ev hanımı & 76 & 80.0 & 83 & 87.3 & \multirow[t]{4}{*}{0.418} \\
\hline & İşçi & 2 & 2.1 & 1 & 1.1 & \\
\hline & Memur & 13 & 13.7 & 10 & 10.5 & \\
\hline & Serbest & 4 & 4.2 & 1 & 1.1 & \\
\hline \multirow[t]{5}{*}{ Eş eğitim düzeyi } & $\begin{array}{l}\text { Okuryazar } \\
\text { değil/okuryazar }\end{array}$ & 3 & 3.2 & 4 & 4.2 & \multirow[t]{5}{*}{0.706} \\
\hline & ilkokul & 29 & 30.5 & 30 & 31.6 & \\
\hline & Ortaokul & 27 & 28.4 & 32 & 33.7 & \\
\hline & Lise & 17 & 17.9 & 17 & 17.9 & \\
\hline & Üniversite & 19 & 20.0 & 12 & 12.6 & \\
\hline \multirow[t]{2}{*}{ Eş çalışma } & Çalışmayan & 11 & 11.6 & 9 & 9.5 & \multirow[t]{2}{*}{0.636} \\
\hline & Çalışan & 84 & 88.4 & 86 & 90.5 & \\
\hline \multirow[t]{3}{*}{ Eş meslek } & İşçi & 34 & 38.6 & 38 & 44.2 & \multirow[t]{3}{*}{0.756} \\
\hline & Memur & 12 & 13.6 & 11 & 12.8 & \\
\hline & Serbest & 42 & 47.7 & 37 & 43.0 & \\
\hline \multirow[t]{3}{*}{ Evlenme yaşı } & 18 ve altı & 34 & 35.8 & 45 & 47.4 & \multirow[t]{3}{*}{0.103} \\
\hline & $19-25$ & 46 & 48.4 & 43 & 45.3 & \\
\hline & 26 ve üzeri & 15 & 15.8 & 7 & 7.3 & \\
\hline \multirow[t]{2}{*}{ Kaçıncı evlilik } & 1 & 95 & 100 & 94 & 98.9 & \multirow[t]{2}{*}{0.316} \\
\hline & 2 & -- & -- & 1 & 1.1 & \\
\hline \multirow[t]{2}{*}{ Akrabalık } & Evet & 19 & 20.0 & 27 & 28.4 & \multirow[t]{2}{*}{0.175} \\
\hline & Hayır & 76 & 80.0 & 68 & 71.6 & \\
\hline Yaşadığı yer & Köy & 34 & 35.8 & 50 & 52.6 & 0.060 \\
\hline & Kasaba & 16 & 16.8 & 10 & 10.5 & \\
\hline & illçe & 15 & 15.8 & 7 & 7.4 & \\
\hline & il & 30 & 31.6 & 28 & 29.5 & \\
\hline Ailenin gelir & 500-1000 TL & 45 & 47.4 & 59 & 62.1 & 0.115 \\
\hline durumu & $1000-2000 \mathrm{TL}$ & 23 & 24.2 & 15 & 15.8 & \\
\hline & 2000 TL ve üzeri & 27 & 28.4 & 21 & 22.1 & \\
\hline Birlikte yaşadıkları & eş+çocuk & 49 & 51.6 & 45 & 47.4 & 0.488 \\
\hline kişiler & eş+eşinin ailesi & 45 & 47.4 & 50 & 52.6 & \\
\hline & eş+kendi ailesi & 1 & 1.1 & -- & -- & \\
\hline
\end{tabular}


Kontrol grubundaki gebeliğinde risk faktörü olmayan gebelerin \%47,4'ünün 25-34 yaş aralığında, \%44,2'sinin ortaokul mezunu, \%87,4'ünün çalışmadığı ve \%28,4'ünün eşiyle akraba olduğu belirlenmiştir. Gebeliğinde risk faktörü olmayan gebelerin $\% 33,7$ 'sinin eşinin ortaokul mezunu ve \%90,5'inin eşinin çalıştığı belirlenmiştir. Gebeliğinde risk faktörü olmayan gebelerin \%62,1'inin gelirlerinin giderinden az, \%52,6'sının köyde yaşadığı, \%52,6'sının eşi ve eşinin ailesi ile yaşadığı belirlenmiştir (Tablo 1).

Tablo 2. Yüksek riskli ve sağlıklı gebelik gruplarının obstetrik öykülerine göre dağılımı

\begin{tabular}{|c|c|c|c|c|c|c|}
\hline \multicolumn{2}{|l|}{ Obstetrik Öykü } & \multicolumn{2}{|c|}{ Yüksek Riskli Gebe } & \multicolumn{2}{|c|}{ Sağlıklı Gebe } & \multirow{2}{*}{$\begin{array}{c}\text { Test Anlamlılık } \\
\text { Değeri } \\
\text { p }\end{array}$} \\
\hline & & $\mathbf{n}$ & $\%$ & $n$ & $\%$ & \\
\hline \multirow[t]{4}{*}{ Gravida } & 1 & 34 & 35.8 & 21 & 22.1 & \multirow[t]{4}{*}{0.124} \\
\hline & 2 & 21 & 22.1 & 24 & 25.3 & \\
\hline & 3 & 21 & 22.1 & 20 & 21.1 & \\
\hline & 4 ve üstü & 19 & 20.0 & 30 & 31.6 & \\
\hline \multirow[t]{4}{*}{ Parite } & 0 & 43 & 45.3 & 28 & 29.5 & \multirow[t]{4}{*}{0.046} \\
\hline & 1 & 18 & 18.9 & 25 & 26.3 & \\
\hline & 2 & 22 & 23.2 & 19 & 20.0 & \\
\hline & 3 ve üstü & 12 & 12.6 & 23 & 24.2 & \\
\hline \multirow[t]{4}{*}{ Yaşayan } & 0 & 44 & 46.3 & 28 & 29.5 & \multirow[t]{4}{*}{0.050} \\
\hline & 1 & 19 & 20.0 & 26 & 27.4 & \\
\hline & 2 & 21 & 22.1 & 20 & 21.0 & \\
\hline & 3 ve üstü & 11 & 11.6 & 21 & 22.1 & \\
\hline \multirow[t]{3}{*}{ Abortus } & 0 & 64 & 67.4 & 65 & 68.4 & \multirow[t]{3}{*}{0.985} \\
\hline & 1 & 23 & 24.2 & 22 & 23.2 & \\
\hline & 2 ve üstü & 8 & 8.4 & 8 & 8.4 & \\
\hline \multirow[t]{3}{*}{ Gebelik haftası } & 0-12 hafta & 17 & 17.9 & 12 & 12.7 & \multirow[t]{3}{*}{0.021} \\
\hline & 13-27 hafta & 27 & 28.4 & 14 & 14.7 & \\
\hline & 28 hafta ve üstü & 51 & 53.7 & 69 & 72.6 & \\
\hline \multirow[t]{2}{*}{ Planlı gebelik durumu } & Evet & 76 & 80.0 & 62 & 65.3 & \multirow[t]{2}{*}{0.023} \\
\hline & Hayır & 19 & 20.0 & 33 & 34.7 & \\
\hline \multirow{2}{*}{$\begin{array}{l}\text { Gebelik öncesi } \\
\text { psikiyatrik tedavi }\end{array}$} & Evet & 2 & 2.1 & 5 & 5.3 & \multirow[t]{2}{*}{0,248} \\
\hline & Hayır & 93 & 97.9 & 90 & 94.7 & \\
\hline
\end{tabular}

Katılımcıların obstetrik öykülerine göre dağılımları incelendiğinde; yüksek riskli gebelik tanısı olan olguların \%35,8'inin ilk gebeliği, \%32,6'sının bir ve üzerinde düşük yaptığı, \%80'inin istenilen gebelik yaşadığı belirlenmiştir. Yüksek riskli gebeliklerde planlı gebelik oranı kontrol grubundaki gebeliğinde risk olmayan gruptan yüksek bulunmuştur $(p=0,0230<0.05)$. Yüksek riskli gebelerin \%97,9' unun gebelikten önce psikiyatrik tedavi almadığı belirlenmiştir (Tablo 2).

Kontrol grubundaki gebeliğinde risk faktörü olmayan gebelerin \%22,1'inin ilk gebeliği, \%31,6'sının bir ve üzerinde düşük yaptığı, \%65,3'ünün planlı gebelik yaşadığı belirlenmiştir. 
Gebeliğinde risk faktörü olmayan gebelerin \%94,7'sinin gebelikten önce psikiyatrik tedavi almadığı belirlenmiştir (Tablo 2).

Tablo 3. Yüksek riskli grup tanı dağılımı (n:95)

\begin{tabular}{lc|cc|c}
\hline & \multicolumn{2}{c}{ Evet } & \multicolumn{2}{c}{ Hayır } \\
\hline Hipertansiyon & $\mathbf{n}$ & $\mathbf{\%}$ & $\mathbf{n}$ & $\mathbf{\%}$ \\
Şiddetli Hiperemezis & 17 & 17.9 & 78 & 82.1 \\
Kilo Alımında Problemler & 12 & 12.6 & 83 & 87.4 \\
İntrauterin Gelişme Geriliği & 10 & 10.5 & 85 & 89.5 \\
Polihidramnios/ Oligohidraamnios & 4 & 4.2 & 91 & 95.8 \\
Prezentasyon Anomalileri & 5 & 5.3 & 90 & 94.7 \\
Diabetes Mellitus & 5 & 5.3 & 90 & 94.7 \\
Preterm/Postterm & 14 & 14.7 & 81 & 85.3 \\
Çoğul Gebelik & 18 & 18.9 & 77 & 81.1 \\
Akut Cerrahi Problemler & 8 & 8.4 & 87 & 91.6 \\
Rh İzoimmunizasyonu & 4 & 4.2 & 91 & 95.8 \\
Antenatal Kanama & 14 & 14.7 & 81 & 85.3 \\
Risk faktörlerinin tespit edildiği hafta & 24 & 25.3 & 71 & 74.7 \\
0-12 hafta & & & & \\
13-27 hafta & 32 & 33.7 & & \\
$\mathbf{2 8}$ hafta ve üstü & 35 & 36.8 & & \\
\hline
\end{tabular}

*Birden fazla riski olan birey sayısı olduğu için $n$ katlanmıştır

Yüksek riskli gebeliğe sahip olgularda hipertansiyon $(\% 17,9)$, şiddetli hiperemezis $(\% 12,6)$, kilo alımında problemler $(\% 10,5)$, intrauterin gelişme geriliği $(\% 4,2)$, polihidramnios veya oligohidraamnios $(\% 5,3)$, prezentasyon anomalileri $(\% 5,3)$, diabetes mellitus $(\% 14,7)$, preterm veya postterm eylem $(\% 18,9)$, çoğul gebelik $(\% 8,4)$, akut cerrahi problemler $(\% 4,2)$, Rh izoimmunizasyonu $(\% 14,7)$, antenatal kanama $(\% 25,3)$ oranında görüldüğü bulunmuştur. (Tablo 3). Tabloda gösterilmemekle birlikte yüksek riskli gebelerin $\% 36,8^{\prime}$ inde iki ve daha fazla sayıda risk faktörü tespit edilmiştir. Risk faktörlerinin tespit edildiği gebelik haftasına bakıldığında; yüksek riskli gebelerin \%36,8'inin gebelikte risk faktörlerinin ikinci trimesterde tespit edildiği belirlenmiştir (Tablo 3). 
Tablo 4. Gruplara göre Beck depresyon ve Beck anksiyete puanlarının değerlendirmesi

\begin{tabular}{|c|c|c|c|c|}
\hline & $\begin{array}{c}\text { Yüksek Riskli } \\
\text { (n:95) }\end{array}$ & $\begin{array}{c}\text { Risk Faktörü } \\
\text { Olmayan (n:95) }\end{array}$ & & \\
\hline & Ort \pm Ss & Ort \pm Ss & $\mathbf{t}$ & $\mathbf{p}$ \\
\hline Beck Depresyon & $12.14 \pm 10.04$ & $10.38 \pm 7.1$ & 0.57 & 0.567 \\
\hline Beck Anksiyete & $13.23 \pm 10.85$ & $14.23 \pm 13.16$ & -1.40 & 0.166 \\
\hline
\end{tabular}

Yüksek riskli gebeliği olan olgular ile gebeliğinde risk faktörü olmayan olguların Beck anksiyete ve depresyon puanları arasında istatistiksel açıdan anlamlı fark bulunmamıştır ( $>>0,05)$ (Tablo 4).

Tablo 5. Yüksek riskli gebeliklerde gebelik öncesi psikiyatrik tedavi alma durumuna göre Beck depresyon ve Beck anksiyete puanlarının değerlendirilmesi (n:95)

\begin{tabular}{|c|c|c|c|c|c|}
\hline \multirow[t]{2}{*}{ Puanlar } & \multicolumn{5}{|c|}{ Psikiyatrik } \\
\hline & Tedavi & $\mathbf{n}$ & Ort \pm Ss & $\mathbf{t}$ & p \\
\hline \multirow[t]{2}{*}{ Beck Depresyon } & Evet & 2 & $25.50 \pm 0.70$ & 11.95 & $0.000^{*}$ \\
\hline & Hayır & 93 & $11.85 \pm 9.95$ & & \\
\hline \multirow[t]{2}{*}{ Beck Anksiyete } & Evet & 2 & $11.00 \pm 7.07$ & -0.444 & 0.728 \\
\hline & Hayır & 93 & $13.28 \pm 10.94$ & & \\
\hline
\end{tabular}

Yüksek riskli gebeliğe sahip olan gebelerin gebelik öncesi tedavi durumları ile depresyon puanları karşılaştırıldığında istatistiksel olarak anlamlı bir ilişki bulunmuştur. $(p=0.000<0,01)$. Yüksek riskli gebeliği olan gebelerin gebelik öncesi tedavi durumları ve anksiyete puanları arasında anlamlı ilişki bulunmamıştır ( $p=0.728>0,05)$ (Tablo 5). Tabloda gösterilmemekle birlikte sağlıklı gebeliğe sahip olan gebelerin gebelik öncesi psikiyatrik tedavi alma durumları ve depresyon puanları $(p=0,325)$ ve anksiyete puanları $(p=0,922)$ arasında anlamlı bir farklılık saptanmamıştır ( $p>0,05)$. 
İstenmeyen gebeliklerde, yüksek riskli ve gebeliğinde risk faktörü olmayan gebelik olgularının depresyon ve anksiyete puanları ile arasında anlamlı bir farklılık saptanmamıştır $(p>0,05)$.

Tablo 6. Beck depresyon ve Beck anksiyete puan ortalamaları arasındaki ilişki (n:190)

\begin{tabular}{lcc}
\hline Puan ortalaması & $\mathbf{p}$ & $\mathbf{r}$ \\
\hline Beck Depresyon & 0.000 & 0.624 \\
Beck Anksiyete & $\mathbf{0 . 0 0 0}$ & $\mathbf{0 . 6 2 4}$ \\
\hline
\end{tabular}

Gebelerin Beck depresyon ve Beck anksiyete puanları arasında pozitif yönlü ve güçlü bir ilişki olduğu ve bu ilişkinin anlamlı olduğu bulunmuştur. Beck depresyon puanı arttıkça ya da azaldıkça Beck anksiyete puanı da artmakta veya azalmaktadır (r:624 p:0,000) (Tablo 6).

\section{TARTIŞMA VE SONUÇ}

Araştırmaya dahil olan 190 gebenin 95'i yüksek riskli gebelik tanısı alan grubu 95 gebe ise normal gebeliği olan kontrol grubunu oluşturdu. Araştırmamızda yüksek riskli gebelik tanısı olan olguların 46'sı $(\% 48,4)$ 25-34, gebeliğinde risk faktörü olmayan gebelerin 45'i $(\% 47,4) 25$ 34 grubundadır (Tablo 1). TNSA (2018) verilerinde Türkiye'de kadınların en yüksek doğurganlıkları yirmili yaşlarında olmaktadır ve yaşa özel en yüksek doğurganlık hızı 25-29 yaş grubunda bulunmaktadır. Kölgelier ve arkadaşlarının (2009) yaptıkları çalışmada, gebelerin \%54,8'i 26-35 yaş grubundadır. Bektaş'ın (2008) çalışmasında 25-34 yaş grubu gebeler \%54,5'i oluşturmaktadır. Pişirgen'in (2011) çalışmasında gebelerin 89'u (\%59,3) 25-34 yaş grubundadır. Çoğu çalışma bulgusu bizim çalışmamızdaki bulguyla benzerlik göstermektedir. Çalışmamızda yüksek riskli gebeler ile gebeliğinde risk faktörü olmayan gebelerin yaş ortalamaları kıyaslandığında anlamlı bir farklılık saptanmamıştır (p:0987, p>0.05). Şahsıvar'ın (2007) çalışmasında da benzer şekilde yüksek riskli gebe ve kontrol grubu yaş ortalamaları açısından değerlendirilmiş ancak anlamlı bir farklılık tespit edilmemiştir ( $p=0.302)$.

Gebelerin eğitim durumları incelendiğinde (Tablo 1), yüksek riskli gebeliği olan olguların 10'u (\%10,5) okuryazar değil/okuryazar, 30'u (\%31,6) ilkokul, 25'i (\%26,3) ortaokul, 10 'u $(\% 10,5)$ lise, 20'si $(\% 21,1)$ üniversite mezunudur. Yüksek riskli gebeliği olmayan kontrol grubundaki gebelerin 13'ü (\%13,7) okuryazar değil/okuryazar, 19'u (\%20,0) ilkokul, 42'si 
(\%44,2) ortaokul, 10'u $(\% 10,5)$ lise, 11'i $(\% 11,6)$ üniversite mezunudur. Yüksek riskli gebeliği olanlara göre riskli gebeliği olmayanlarda ortaokul mezunu eğitim oranı yüksek bulunmuştur (p:0,044). Pişirgen'in (2011) çalışmasında ise riskli gebelik tanısı almış gebelerin \%46,7'si ilköğretim mezunu, \%24'ü lise mezunu ve \%29,3'ü üniversite mezunu olduğu belirlenmiştir. Aynı çalışmada riskli gebeliği olmayan olguların \%29,3'ü ilköğretim, \%40,0'ı lise, \%30,7'si üniversite mezunu olduğu saptanmıştır. Pesavento ve arkadaşlarının (2005) çalışmasında, risksiz gebelerin \%6'sı, risklilerin \%24'ü ilköğretim, risksiz gebelerin \%58'i, risklilerin \%58'i lise, risksiz gebelerin \%36'sı, risklilerin \%18'i üniversite-yüksekokul düzeyinde eğitim almış oldukları görülmüştür.

Yüksek riskli gebelerin 19'u $(\% 20,0)$ bir işte çalışmaktadır. Yüksek riskli gebeliği olmayan gebelerin 12 'si $(\% 12,6)$ bir işte çalışmaktadır. Yüksek riskli gebeliği olan olguların 76'sı $(\% 80,0)$ ev hanımı, sağılılı gebelerin 83'ü $(\% 87,4)$ ev hanımı olduğu bulunmuştur (Tablo 1). Pişirgen'in (2011) yaptığı çalışmada \%58,6'sının ev hanımı olduğu bulunmuştur.

Gebelerin gebelikteki risk durumlarını eşlerinin eğitim düzeylerine göre incelediğimizde yüksek riskli ve sağlıklı gebelik grubundaki gebe eşlerinin öğrenim durumu açısından karşılaştırıldığında anlamlı farklılık bulunmamıştır (p:0,706) (Tablo 1). Kılıç ve arkadaşlarının (2007) yaptıkları çalışmada, gebelerin gebelikteki risk durumları eşlerinin eğitim düzeylerine göre incelendiğinde istatistiksel olarak anlamlılık saptanmamıştır ( $p=0.49)$. Pişirgen'in (2011) çalışmasında da benzer sonuç bulunmuş ve gebe eşlerinin eğitim düzeyleri açısından bir farklııı tespit edilmemiştir $(p=0,254)$. Çalışmaya dahil olan gebeler eş mesleği açısından değerlendirildiğinde iki grup gebe eşleri meslek açısından karşılaştırıldığında anlamlı bir farklılık saptanmamıştır (p:0,756) (Tablo 1). Şahsıvar'ın (2007) yaptığı çalışmada eşleri memur olan gebelerde riskli gebelik görülme durumu istatistiksel olarak anlamlı derecede düşük olduğu belirtilmiştir ( $p=0.038)$. Pişirgen'in (2011), Kılıç ve arkadaşlarının (2007) çalışmasında da bizim çalışmamıza benzer şekilde iki grup arasında anlamlı farklılık saptanmamıştır $(p=0.112)$.

Çalışmamıza katılan gebelerin evlenme yaşlarına göre risk durumlarına bakıldığında; 18 yaş ve altı gebelerin 34'ü $(\% 35,8)$ risk taşırken, $45^{\prime}$ inde $(\% 47,4)$ risk faktörü bulunmamıştır. 1925 yaş aralığındaki gebelerin 46'sı $(\% 48,4)$ risk taşırken, 43'ünde $(\% 45,3)$ risk tespit edilmemiştir. 26 yaş ve üstü gebelerin $18^{\prime} \mathrm{i}(\% 15,8)$ riskli gebelik iken 7 'sinin $(\% 7,4)$ risk taşımadığı belirlenmiştir. Sağlıklı ve yüksek riskli iki grup arasında istatiksel açıdan anlamlı bir ilişki saptanmamıştır (p:0,103) (Tablo 1). Şahsıvar'ın (2007) ve Pişirgen'in (2011) çalışmasında 
da benzer sonuçlar elde edilmiştir. Evlenme yaşının gebeliğin risk durumu üzerine etkisi olmadığı düşünülmüştür.

Araştırmaya katılan yüksek riskli gebelerin \%20'sinin, kontrol grubu gebelerin \%28,4'ünün eşleriyle akrabalıkları olduğu bulunmuştur (Tablo 1). Tekbaş ve arkadaşlarının (2005) yaptıkları çalışmalarında katılımcıların \%14,9"u anne-babasının akraba olduğunu belirtmiştir. Pişirgen'in (2011) çalışmasında her iki grubunda akrabalık oranı \%12 olarak bulunmuş ve gruplar arasında istatistiksel açıdan anlamlı bir farklılık tespit edilmediği belirtilmiştir. Köksal'ın (2016) çalışmasında kontrol grubu gebelerin \%5,1'i, yüksek riskli gebelerin ise \%11'i akraba olarak bulunmuş ve istatistiksel olarak anlamlı farklılık bulunmamıştır.

Gebeler ailelerinin gelir durumları açısından karşılaştırıldığında yüksek riskli gebe grubu ile kontrol grubu arasında anlamlı farklılık bulunamadı (p:0,115) (Tablo 1). Pişirgen'in (2011) çalışmasında yüksek riskli gebelik tanısı alan olguların gelir düzeyi, kontrol grubuna göre düşük bulunmuştur ( $p=0.027)$. Köksal'ın (2016) çalışmasında gebelerin gebelikteki risk durumları toplam aylık gelir düzeylerine göre incelendiğinde istatistiksel olarak anlamlılık saptanmamıştır. Kılıç ve arkadaşlarının (2007) yaptıkları çalışmada da bizim çalışmamıza benzer şekilde gebelerin gebelikteki risk durumları toplam aylık gelir düzeylerine göre incelendiğinde istatistiksel olarak anlamlılık saptanmamıştır $(p=0.28)$.

Gebeler birlikte yaşadıkları kişiler açısından gruplandırıldıktan sonra karşılaştırılmış ve benzer şekilde gruplar arasında istatistiksel olarak anlamlı farklılık tespit edilmemiştir (p:0,488) (Tablo 1). Pişirgen'in (2011) ( $p=0.843$ ) ve Şahsıvar'ın (2007) ( $p=0.474$ ) çalışmalarında gebelerin birlikte yaşadıkları kişiler açısından yapılan karşılaştırmada çalışmamıza benzer şekilde anlamlı farklılık tespit edilmemiştir.

Araştırmada gebelerin obstetrik özellikleri değerlendirildiğinde; gebelerin \%57,9'unun ilk gebeliğidir. Yüksek riskli gebelerin $\% 35,8^{\prime} i$ ve kontrol grubundaki sağlıklı gebelerin \%22,1'inin ilk gebeliğidir (Tablo 2). Kılıçarslan'ın (2008) yaptığı çalışmada katılımcıların \%56,5"inin ilk gebeliğidir. Yüksek riskli ve kontrol grubu gebelerin toplam gebelik sayısı, yaşayan çocuk sayısı, düşük sayısı ortalamaları bakımından grupların benzer olduğu saptanmıştır. Fakat canlı doğum sayısı özelliklerinde hiç canlı doğumu olmayan yüksek riskli gebeliklerde, kontrol grubundaki gebelere göre anlamlı derecede daha yüksek bulunmuştur (p:0,046) (Tablo 2). Pişirgen'in (2011) çalışmasında parite 3 ve üstü olma oranı, kontrol grubuna göre yüksek bulunmuştur. Şahsıvar'ın (2007) çalışmasında ise parite ile riskli gebelik 
arasında istatistiksel olarak anlamlı bir ilişki bulunmamıştır. Gebelik haftası kontrol grubundaki gebelerde yüksek riskli gebeliklere göre anlamlı derecede daha yüksek bulunmuştur. Yüksek riskli gebeliklerde, kontrol grubundaki gebelere göre istenilen gebelik ortalaması anlamlı olarak yüksek iken, kontrol grubundaki gebeliklerde istenmeyen gebelik oranı anlamlı derecede daha yüksek bulunmuştur. Gebeliğin istenme durumu BDÖ ve BAÖ ortalama puanları arasında anlamlı bir ilişki saptanmamıştır. Pişirgen'in (2011) çalışmasında gebeliğin istenip istenmediği incelendiğinde, iki grup arasında istatistiksel olarak anlamlı bir fark görülmemiştir. Şahsıvar'ın (2007) yaptığı çalışmada da istatistiksel olarak anlamlı fark gözlenmemiştir.

Araştırmada yüksek riskli gebeliği olanlarda hipertansiyon $(\% 17,9)$, şiddetli hiperemezis (\%12,6), kilo alımında problemler (\%10,5), intrauterin gelişme geriliği $(\% 4,2)$, polihidramnios veya oligohidraamnios $(\% 5,3)$, prezentasyon anomalileri $(\% 5,3)$, diabetes mellitus $(\% 14,7)$, preterm veya postterm eylem $(\% 18,9)$, çoğul gebelik $(\% 8,4)$, akut cerrahi problemler $(\% 4,2)$, Rh izoimmunizasyonu (\%14,7), antenatal kanama (\%25,3) görüldüğü bulunmuştur (Tablo 3). Pesavento ve arkadaşlarının (2005) İtalya'da riskli gebeliği olan 50 kadın üzerinde yaptıkları bir çalışmada, riskli gebelik tanıları incelendiğinde; \%32'sinde preterm eylem, \%12'sinde hipertansif hastalıklar, \%10'unda plasentanın erken ayrılması, \%8'inde erken membran rüptürü, \%8'inde düşük tehdidi, \%6'sında oligohidroamnioz, \%4'ünde plasenta previa, \%4'ünde intrauterin gelişme geriliği, \%2'sinde şiddetli hiperemezis gravidarum, \%2'sinde gestasyonel diyabetes mellitus bulunmuştur. Kossakowska'nın (2016) Polonya'da sağlıklı ve riskli gebelik grupları arasında yaptığı ve 112 riskli gebenin alındığı bir çalışmada \%20,5'inde preterm eylem, \%40,2'sinde düşük tehdidi, \%15,2'sinde gestasyonel hipertansiyon, \%24,1'inde gebeliğinde toksoplazma-hipertroidi-diyabet tanıları belirtilmiştir. Köksal'ın (2016) çalışmasında \%18,9'u preterm eylem, \%17,3'ü gebeliğin indüklediği hipertansiyon, \%15’i intrauterin gelişme geriliği, \%12,6'sı amniyon mayi bozuklukları, \%11,8'i çoğul gebelik, \%11'i makrozomi, \%3,9'u plasenta previa, \%3,1'i gestasyonel diyabet, \%1,6'sı malrotasyon, \%1,6'sı fetal anomali, \%1,6'sı karaciğer fonksiyon bozukluğu, \%0,8'inde derin ven trombozu ve \%0,8'inde trombositopeni saptanmıştır. Bizim çalışmamızda ve yapılan diğer araştırmalarda olduğu gibi, bu gebeler risk durumlarına göre seçilerek bu araştırmalara alındıkları için, gebelikte görülen risk etkenlerinin toplumdaki dağılımı sıklıklarını göstermemektedir. Literatürde daha önce komplikasyonlu gebelik geçiren gebelerin sonraki gebeliklerinde de 
komplikasyon yaşama olasılıklarının, riski olmayan gebelere göre daha fazla olduğu belirtilmektedir (Taşkın, 2016).

Yüksek riskli grubundaki gebelerin \%36,8'inin risk faktörü ikinci trimesterde tespit edildi (Tablo 3). Bu gebelerin \%12,6'sında risk faktörü başlamadan önce stresli bir durum mevcut idi. Çalışmamızdaki riskli gebelerin \%80'i eş desteği almaktaydılar. Arslan ve Korkmaz'ın (2005) yüksek riskli gebeler üzerinde yaptıkları çalışmada ise gebelerin \%80,76'sının eşlerinden destek aldıkları saptanmıştır. Pişirgen'in (2011) çalışmasında riskli grubundaki gebelerin \%36’sının risk faktörü üçüncü trimesterde tespit edildiği saptanmıştır. Bu gebelerin \%21,3'ünde risk faktörü başlamadan önce stresli bir durum olduğu ve riskli gebelerin \%84'ünün eş desteği aldıkları saptanmıştır.

Gebelerin psikiyatrik tedavi durumlarına göre BDÖ ve BAÖ’nden aldıkları puan ortalamaları arasında da istatistiksel olarak anlamlı fark tespit edilmedi. Yüksek riskli gebelerden gebelik öncesi psikiyatrik tedavi alan kişi sayısı 2'dir ve BDÖ ortalama puanları (25.50 \pm 0.70$)$ arasındaki fark anlamlı bulundu (p:0,000) (Tablo 5). Arslan'ın (2010) çalışmasında daha önce psikiyatrik tedavi alma öyküsü anksiyete için bir risk faktörü olarak saptanmıştır.

Çalışmamıza katılan gebelerin \%46,3'ünde BDÖ düzeyleri 17 ve üzeri, \%66,2'sinde BAÖ düzeyleri 16 ve üzeri olarak bulundu. Yapılan çalışmalarda gebelikte depresyon ve depresif semptom görülme sıklığının \%5-51 arasında değiştiği bulunmuştur. Türkiye'de bu konuda sınırlı sayıda çalışma mevcut olmakla birlikte, BDÖ puanı göre (kesme puanı 17 ve üzeri) yapılan çalışmalar da gebelikte depresif belirti görülme sıklığını; Karaçam ve Ançel (2009) \%27,3, Sevindik (2005) \%36,3 olarak bulmuşlardır. Farklı ölçeklerle yapılan çalışmalarda; Nicholson ve arkadaşları (2006) depresif belirtilerin prevelansını \%15, Bödecs ve ark. (2009) gebelik depresyonu sıklığını \%17,9, Kurki ve ark. (2000) yaptıkları çalışmada \%30 olarak bulmuşlardır. Yılmaz'ın çalışmasında (2013) gebelerde depresyon sıklığı \%25,5 olarak bulunmuştur. Yüksek riskli gebelerin ise \%28,4'ünde BDÖ düzeyleri 17 ve üzeri bulundu. Yüksek riskli gebelerin \%32,6'sında BAÖ düzeyleri 16 ve üzeri bulundu. Çalışmamıza katılan gebelerin ortalama BDÖ ve BAÖ düzeyleri, kontrol grubu ve yüksek riskli grupta istatistiksel olarak anlamlı bulunmadı. Yüksek riskli gebelerin anksiyete toplam puan ortalaması $13.23 \pm 10.85$, depresyon toplam puan ortalaması $12.14 \pm 10.04$ iken, kontrol grubu için anksiyete toplam puan ortalaması $14.23 \pm 13.16$, depresyon toplam puan ortalaması $10.38 \pm 7,1$ olarak saptanmıştır (Tablo 4). Gebelerin BDÖ ve BAÖ puan ortalamaları arasında anlamlı bir ilişki olduğu bulunmuştur (Tablo 6). Pişirgen'in (2011) yaptığı çalışmada BDÖ ortalaması, riskli 
gebelerde risksiz gebelere göre istatistiksel olarak anlamlı derecede daha yüksek bulunmuştur $(p<0.001)$. Şahsıvar'ın (2007) çalışmasında ortalama depresyon düzeyleri açısından vaka ve kontrol grupları arasında istatistiksel olarak anlamlı farklılık saptanmıştır. Pesavento ve arkadaşlarının (2005) çalışmalarında gebelerin \%12,0'ında (tamamı riskli grupta), riskli gebelerin ise \%24,0'ında BDÖ düzeyleri 17 ve üzeri olarak bulunmuştur. Kurki ve arkadaşları (2000), depresyonun preeklampsi riskini 2,5 kat arttırdığı, depresyon ve anksiyetenin ise bu riski 3,1 kat arttığını bulmuşlardır. Literatürdeki çalışma sonuçları gebelerde depresyonun arttığını ve özellikle riskli gebeliği olanlarda artışın daha belirgin olduğunu göstermektedir. Gümüşdaş ve arkadaşları (2014) yaptıkları çalışmada riskli olan ve riski olmayan gebelerin psikososyal sağlıklarını karşılaştırarak riskli olan gebelerde stres, kaygı ve bunlara bağlı depresyon gelişme durumunun risksiz gebelere oranla daha yüksek olduğunu bulmuştur

Sonuç olarak; bu araştırmada yüksek riskli gebelerin \%28,4'ünde depresyon, \%32,6'sında orta ve şiddetli düzeyde anksiyete tespit edildi. Yüksek riskli gebelerde depresyon ve anksiyete görülme oranı, normal gebelerle benzer bulundu $(p>0,05)$. Yüksek riskli gebelerde gebelik öncesi psikiyatrik tedavi alanların depresyon ortalamalarının yüksek olduğu belirlendi $(p<0,05)$. Depresyon belirtilerinin gözlendiği gebelerin anksiyete ortalamalarının da yüksek olduğu belirlendi $(p<0,05)$. Çalışmamızda yüksek riskli gebeler diğer gebelere benzer oranda anksiyete ve depresyon yaşamakta ve gebeliğin yüksek riskli olması bu oranları etkilememektedir. Çalışmamıza göre yüksek riskli gebelerin yaşadığı gebelik öncesi veya gebelik sırasında oluşan risk faktörlerinin anksiyete ve depresyon oluşmasında etkili olmadığı söylenebilir.

Araştırmadan elde edilen verilere dayalı olarak; Ebelerin/hemşirelerin doğum öncesi gebe izlemlerinde tüm gebelere risk değerlendirmesi yapmanın yanında anksiyete ve depresyon değerlendirmesi yapmalıdır. Ebeler/hemşireler gebelikte kaygı ve stresin sıklıkla endişe ve depresyonla birleştiğini ve tablonun daha olumsuz bir hal aldığını bilmeli, gebelere bu bilinçle yaklaşmalı ve gerekirse yüksek riskli gebelerin daha fazla desteklenmesi için aile üyeleri ile iş birliği yapmalıdır. Yüksek riskli gebelerde anksiyete ve depresyon düzeylerinin düzenli aralıklarla değerlendirilmesi, görev alan tüm ebe/hemşirelerin bakım ve danışmanlık uygulamalarının yeri ve önemi kanıta dayalı olarak yeniden sorgulanmalıdır. Araştırmada yüksek riskli ve kontrol grubu gebelerin anksiyete ve depresyon ölçeklerinden aldığı puanların benzer olduğu dikkate alındığında Türkiye'nin farklı bölgelerinde daha büyük ve farklı gebe gruplarıyla çalışmanın tekrarlanması önerilmektedir. 


\section{KAYNAKLAR}

Arslan B. (2010). Gebelerde Anksiyete ve Depresyonla iliş̧kili Sosyodemografik Özellikler. Uzmanlık Tezi, Süleyman Demirel Üniversitesi, Tıp Fakültesi Aile Hekimliği Anabilim Dalı, Isparta.

Arslan H., Korkmaz N. (2005). Kısmi Yatak İstirahati İle Hastanede Yatan Yüksek Riskli Gebelerin Yaşadığı Fiziksel ve Psikolojik Sorunlar. Perinatoloji Dergisi, 13(2), 1-11.

Bektaş E. (2008). Hastanemiz Gebe Polikliniğine Başvuran Gebelerde Normal Doğum ve Tercihi ve Nedenleri İle Illgili Anket Çalışması. Uzmanlık Tezi, Dr. Lütfi Kırdar Kartal Eğitim Araştırma Hastanesi Aile Hekimliği Anabilim Dalı, İstanbul.

Bödecs T., Horvath B., Kovacs L., Diffellne Nemeth M., Sandor J. (2009). Prevalence of Depression and Anxiety in Early Pregnancy on a Population Based Hungarian Sample. Orvosi Hetilap, 150(41),1888-1893.

Dugalic M. G. (2013). Frequency of Perinatal Depression in Serbia and Associated Risk Factors. Journal of Women's Health Care, 2(2), 122.

Erdem Ö., Bucaktepe G. E., Özen Ş., Kara İ.H. (2010). Prepartum ve Postpartum Dönemde Annelerin Depresyon ve Kaygı Düzeylerinin İncelenmesi. Düzce Tıp Dergisi, 12(3), 24-31.

Gümüşdaş M., Apay S. E., Özorhan E. Y. (2014). Riskli Olan ve Olmayan Gebelerin Psiko-Sosyal Sağlıklarının Karşılaştııılması. Sağıık Bilimleri Ve Meslekleri Dergisi, 1(2), 32-42.

Hisli N. (1988). Beck Depresyon Envanteri'nin Geçerliği Üzerine Bir Çalışma. Psikoloji Dergisi, 6(22), 118-126.

Hisli N. (1989). Beck Depresyon Envanteri’nin Üniversite Öğrencileri İçin Geçerliği, Güvenirliği. Psikoloji Dergisi, $7(23), 8-13$.

Karaçam Z., Ançel G. (2009). Depression, Anxiety and İnfluencing Factors in Pregnancy: A Study in A Turkish Population. Midwifery, 25(4), 344-356.

Kılıç S., Uçar M., Temir P., Erten Ü., Şahin E., Karaca B., Yüksel S., Özkır F. (2007). Hamile Kadınlarda Doğum Öncesi Bakım Alma Sıklığı ve Bunu Etkileyen Faktörler. Koruyucu Hekimlik Bülteni, 6(2), 91-97.

Kılıçarslan S. (2008). Edirne Şehir Merkezindeki Son Trimester Gebelerin Sosyodemografik Özellikleri, Yaşam Kaliteleri, Kaygı Düzeyleri. Uzmanlık Tezi, Trakya Üniversitesi, Tıp Fakültesi Aile Hekimliği Anabilim Dalı, Edirne.

Koss J., Bidzan M., Smutek J. And Bidzan L. (2016). Influence of Perinatal Depression on Labor-Associated Fear and Emotional Attachment to The Child in High-Risk Pregnancies and The First Days After Delivery. Medical Science Monitor, 22, 1028-1037.

Kossakowska K. (2016). Incidence and Determinants of Postpartum Depression Among Healthy Pregnant Women and High-Risk Pregnant Women. Advances in Psychiatry and Neurology, 25, 1-21.

Köksal H. K. (2016). Sosyodemografik Verilerin Yüksek Riskli Gebelikler Üzerine Etkisinin İncelenmesi. Uzmanlık Tezi. Cumhuriyet Üniversitesi, Tıp Fakültesi Aile Hekimliği Anabilim Dalı, Sivas.

Kölgelier S., Demir Arslan H., Kataş B., Güler G. (2009). Gebelerde Toxoplazma Gondi Seroprevalansı. Dicle Tıp Dergisi, 36(3), 170-172.

Kurki T., Hiilesmaa V., Raitasalo R., Mattila H., Ylikorkala O. (2000). Depression and Anxiety in Early Pregnancy and Risk For Preeclampsia. Obstetrics and Gynecology, 95(4), 487-490. 
Marakoğlu K., Şahsıvar M. Ş. (2008). Gebelikte Depresyon. Türkiye Klinikleri Journal of Medical Sciences, 28, 525532.

Nicholson W. K., Setse R., Hill-Briggs F., Cooper L. A., Strobino D., Powe N. R. (2006). Depressive Symptoms and Health-Related Quality of Life in Early Pregnancy. Obstetrics \& Gynecology, 107(4), 798-806.

Ölçer Z., Oskay U. (2015). Yüksek Riskli Gebelerin Yaşadığı Stresörler ve Stresle Baş Etme Yöntemleri. Hemşirelikte Eğitim ve Araştırma Dergisi, 12(2), 85-92.

Özkan M., Kaçmaz N., Anuk D., İbrahimoğlu L. (2004). Yüksek Riskli Gebeliklerde Psikiyatrik Morbidite. İstanbul Tıp Fakültesi Mecmuası, 67(4), 210-217.

Paşalak Ş. İ. (2016). Yüksek Riskli Gebelik Nedeniyle Hastanede Yatak İstirahatinde Olan Gebelerin Gebeliğe Uyum Düzeyleri ve Etkileyen Bazı Faktörlerin Belirlenmesi. Yüksek Lisans Tezi, Koç Üniversitesi, Sağlık Bilimleri Enstitüsü Doğum ve Kadın Sağlığı Hemşireliği, İstanbul.

Pesavento F., Marconcini E., Drago D. (2005). Quality Of Life and Depression in Normal and in High-Risk Pregnancy. Analysis of A Sample Of 100 Women. Minerva Ginecologica, 57(4), 451-60.

Pişirgen T. N. (2011). Riskli Gebeliklerde Depresyon ve Anksiyete Düzeylerinin Değerlendirilmesi. Tıpta Uzmanlık Tezi, Eskişehir Osmangazi Üniversitesi, Tıp Fakültesi Aile Hekimliği Anabilim Dalı, Eskişehir.

Satyapriya M., Nagarathna R., Padmalatha V., Nagendra H.R. (2013). Effect of Integrated Yoga on Anxiety, Depression and Well Being in Normal Pregnancy. Complementary Therapies in Clinical Practice, 19(4), 230-236.

Serçekuş P., Okumuş H. (2004). Yüksek Riskli Gebelerde Uzun Süre Hastanede Yatmanın Etkileri. Atatürk Üniversitesi Hemşirelik Yüksekokulu Dergisi, 3(7), 107-111.

Sevindik F. (2005). Elazığ İlinde Gebelikte Depresyon Prevalansı ve Etkileyen Faktörler. Yüksek Lisans Tezi, Fırat Üniversitesi, Sağlık Bilimleri Enstitüsü, Elazığ.

Shin H. S., Kim J. H. (2011). Music therapy on anxiety, stress and maternal-fetal attachment in pregnant women during transvaginal ultrasound. Asian attachment in pregnant women during transvaginal ultrasound. Asian Nursing Research, 5(1), 19-27.

Şahin E. M., Kılıçarslan S. (2010). Son Trimester Gebelerin Depresyon ve Kaygı Düzeyleri ile Bunları Etkileyen Etmenler. Trakya Üniversitesi Tıp Fakültesi Dergisi, 27(1), 51-58.

Şahsıvar Ş. M. (2007). Riskli Gebeliklerde Depresyon ve Yaşam Kalitesinin Değerlendirilmesi. Uzmanlık Tezi, Selçuk Üniversitesi, Meram Tıp Fakültesi Aile Hekimliği Anabilim Dalı, Konya.

Taşkın L. (2016). Doğum ve Kadın Sağlığı Hemşireliği. Ankara. Koç Yayınları.

Tekbaş F. Ö., Oğur R., Uçar M. (2005). Genç Erişkin Erkekler Arasında Akraba Evliliği Sıklığının ve Nedenlerinin Araştırılması. Türk Silahlı Kuvvetleri Koruyucu Hekimlik Bülteni, 4(3), 120-128.

TNSA: Türkiye Nüfus ve Sağlık Araştırması 2018. Hacettepe Üniversitesi Nüfus Etütleri Enstitüsü. (2019). http://www.hips.hacettepe.edu.tr/tnsa2018/rapor/TNSA 2018 ana Rapor.pdf, (25.12.2019).

Tunç S., Yenicesu O., Çakar E., Özcan H., Pekçetin S., Danışman N. (2012). Antenatal Dönemde Anksiyete ve Depresyonun Görülme Sıklığı ve İlişkili Faktörler The Journal Of Gynecology-Obstetrics and Neonatology, 9(35), 1431-1435. 
Ulusoy M., Şahin H.N., Erkmen Hüsnü., (1998). Turkish Version of the Beck Anxiety Inventory: Psychometric Properties. Journal of Cognitive Psychotherapy, 12(2), 163-172.

Yılmaz A. E. (2013). Türkiye Cumhuriyeti Ankara Üniversitesi Sağlık Bilimleri Enstitüsü Ankara'da Bir Eğitim Ve Araştırma Hastanesi Kadın Hastalıkları Ve Doğum Polikliniği’ne Başvuran Gebelerde “Edinburgh Doğum Sonrası Depresyon Ölçeği" İle Depresyon Sıklığı ve İlişkili Etmenler. Yüksek Lisans Tezi, Ankara Üniversitesi Sağlık Bilimleri Enstitüsü Halk Sağlığı Anabilim Dalı, Ankara 